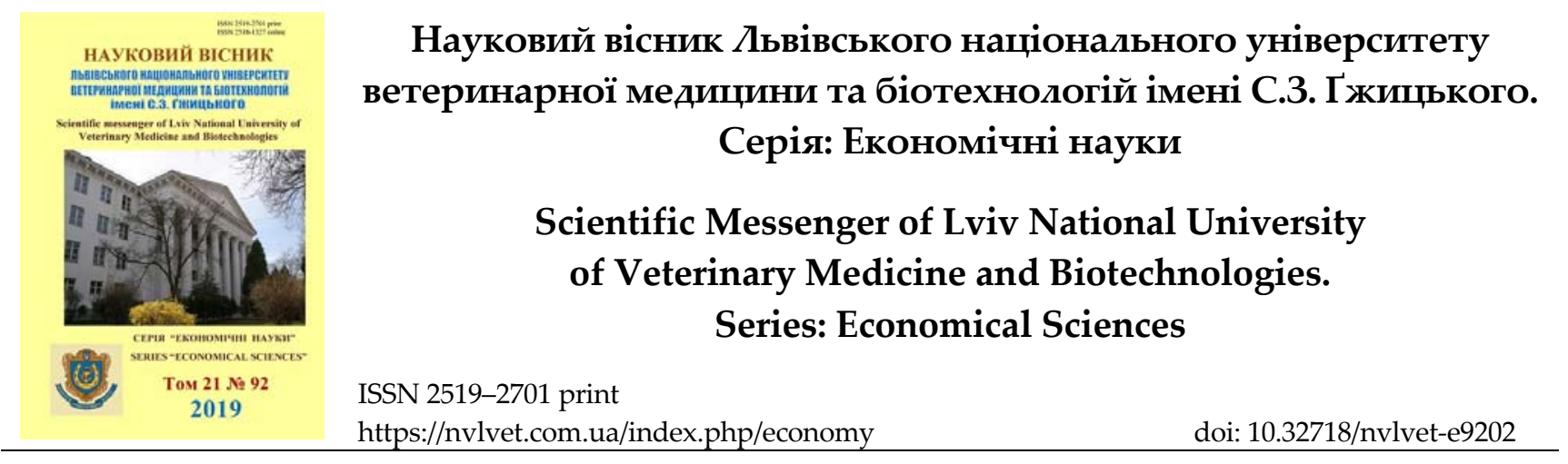

UDC 339.9

\title{
The marketing innovation and the innovation technology in food industry enterprises
}

\author{
N. Voytovych, Y. Polyak \\ Stepan Gzhytskyi National University of Veterinary Medicine and Biotechnologies Lviv, Ukraine
}

Article info

Received 16.01.2019 Received in revised form 20.02.2019

Accepted 21.02.2019

Stepan Gzhytskyi National University of Veterinary Medicine and Biotechnologies Lviv, Pekarska Str., 50, Lviv, 79010, Ukraine. Tel.: +38-032-239-26-39 E-mail:marketing@lvet.edu.ua, strategy_natali@ukr.net

Voytovych, N., \& Polyak, Y. (2019). The marketing innovation and the innovation technology in food industry enterprises. Scientific Messenger of Lviv National University of Veterinary Medicine and Biotechnologies. Series: Economical Sciences, 21(92), 9-14. doi: 10.32718/nvlvet-e9202

Growing competition in the world determines the importance of innovation technology between countries. High-tech markets encourage the inventors to apply their inventions to commercial project. Many new trends on the world markets depend on factors that generate the ideas and their capacity to be absorbed. Development of new technologies in foodservice is considered a luxury as the sector is comprised predominantly by small and medium size businesses that may not be able to afford the heavy costs involved. However, rapid advancements in information technology have allowed dedicated suppliers to foodservice businesses to develop such innovative products or services which help to be successful on the market. Such hardware or software developments enable food and beverage outlets to increase quality of product, productivity and profitability. This review attempts to provide in-depth discussion and enhance understanding on innovation technology in foodservice enterprises. An article was conducted of a detailed analysis for EU countries food service industry. Analysis shows that international chains have a very strong position in the quick service segment. Technology is developing at an ever-increasing pace and dramatically changes business models in the hospitality industry. In the new economy, organizations that have the ability to develop and adopt the invention in a short period of time and profitably apply it in all areas of business reach competitive advantage over the competition in time. The growing importance of innovation in function of achieving a sustainable competitive advantage determined a brand new concept and innovation classification. Nowadays, the term innovation means not only a significant improvement in process and product technology, but it refers more to the innovation process in the field of human resources, especially in marketing management. For the above mentioned reasons, the paper pays special attention to the marketing innovation analysis and the increasingly significant impact it has on the process of achieving sustainable competitive advantage. The main goal of this article is analysis the theoretical and practical contexts concerning marketing innovation, innovation technology in foodservice enterprises. fer.

Key words: marketing innovation, food industry enterprises, innovation technology, technology trans-

Introduction

The differences in political and economic scenario over the centuries have given rise to vast differences in technological capabilities among nations. These technological differences constitute a serious hurdle in the pursuit of globalization. The global production process is fast changing and is now getting increasingly dispersed to make use of the efficient global resources.

In terms of food service technology, that it has come a long way since its beginnings. The dynamic nature of technology has contributed to the existence of various definitions and concepts of technology that are related to technology transfer. The discussion of the concept of technology transfer is crucial in getting a clear understanding of the nature of technology and examining what the technology consists of.

Argue (Slack et al., 2007) that in operations management firms compete against five key areas namely quality, cost, speed, dependability and flexibility. They also do mention training but they do not expand on it as it only contributes to the five areas and cannot be measured directly. Researchers in hospitality and foodservice related research, have argued the positive effects of the utilisation of technology in areas such as quality (Lee et al., 2003; Woon \& Sunny, 2006), cost control (Riley, 2005), speed 
(Prasad et al., 2005), dependability (Davis et al., 2008; Radosevic \& Ciampi Stancova, 2015), challenging the negative image (Pilato et al., 2017), flexibility and employee training (Anon, 2008).

Particularly acute is the issue of survival and competition in the market of major European food manufacturers such as Unilever, Sun Interbrew, Baltic Beverages Holding, Kraft Food's, Nestle, using state-of-the-art technology. Increasingly important issues are the choice of hightech equipment, minimizing raw material consumption and energy savings, and more efficient use of personnel. In the face of fierce competition, the problem of equipment procurement and technology implementation is intensifying. Technological innovations in the food industry are carried out in three directions: basic production (production of products), packaging and utilization of waste products. Implementation of these innovations may be varied depending on the degree of interconnection of technological processes and the availability of financial resources. However, technological innovation is a factor in the further development of product innovations, which in turn contributes to the development of infrastructure and marketing innovations. All this creates the basis for the further development and increase of efficiency of the enterprises of the food-processing industry.

The diffusion of technology to the process that involves does not only concern the transmission of knowledge but it is also relates to a learning process where technological knowledge is continually accumulated into human resources that are engaged in production activities. A successful technology transfer will eventually lead to a deeper and wider accumulation of knowledge. The technology transfer concept is not only concerned about the transfer of technological knowledge or information but also the technology recipient's capability to learn and absorb technology into the production function (Maskus, 2003).

Since technology transfer provides many dimensions, it has often been used to describe the process by which ideas and concepts are moved from the laboratory to marketplace (Phillips, 2002), the transfer and knowledge and concept from developed to less technologically developed countries (Putranto et al., 2003) and the transfer of inventive activities to secondary users.

From this flows our main purpose to study the marketing innovation and the innovation technology in food industry enterprises and what will be contributing to the competitiveness of the food sector using a number of functions and to help their economic development.

\section{Theoretical background}

\section{The define innovation}

A review of literature on innovation technology reveals that it is a complex, difficult process even when it occurs across different functions within a single product division of a single company (Smith and Alexander, 1999; Kidder, 2000; Tidd \& Bessant, 2009).

To define innovation one might return to the Latin Origin of the word. Innovation or "innovare", which means "to make something new", leads to several conclusions of its deeper meaning.
To make something new one has to:

- Generate or realize a new idea (invention and creativity).

- Develop this idea into a reality or product (realization).

- Implement and market this new idea (implementation).

The advantage of specifically including realization in the definition of innovation lies in identifying a clear time in the lifecycle of innovation, where the invention progresses from idea to reality. The realization phase transforms the invention into a producible product and therefore plays a crucial part in the process of innovation.

Implementation should be defined in innovation, to indicate the importance to market and the real or perceived need that exists. No invention may claim to be an innovation, before it has been implemented into the market. The acceptance of the invention into the market changes it to the status of innovation. Therefore, to define innovation, the following quotes come very close to the truth, as understood in the discipline of innovation.

An invention is essentially the creation of a new device. An innovation additionally entails commercial or partial application of the new device ... first application of an invention (Sahal, 1977).

Innovation is the process by which an invention is first brought into use. It involves the improvement or refinement of the invention, the initial design and production of prototypes. Pilot plant testing and construction of production facilities ... diffusion is the process of the spread of the innovation into general use as it is adopted by more and more users (Girifalco, 1991).

Proposed by Berry \& Taggart ... we look upon innovation as the total process from the inception of an idea through to the manufacture of a product and finally to its ultimate sale. It therefore includes invention and the many stages of implementation such as research development, production and marketing (Berry \& Taggart, 1994).

Past literatures have referred innovation technology as the know-how to suit local conditions, with effective absorption and diffusion both within and across countries (Kanyak, 1999; Chung, 2001). Other early researchers for example (Craft et al., 2015) defines innovation technology as transmission of know-how (knowledge) which enable the recipient enterprise to manufacture a particular product or provide a specific service.

\section{Marketing innovation and their importance}

In the modern economy organizations that understand the new rules of marketing develop relationships directly with consumers (Scott, 2013). The main objective of marketing innovation is to improve the identification process and profitable satisfaction of customer needs. By implementation of new marketing methods and activities organization aims to establish a closer relationship with customers and brings them into a situation when customers become promoters of the organization - a condition in which consumers are loyal to the organization and recommend it to their reference groups (Kotler \& Keller, 2006). Despite the aforementioned, other objectives of marketing innovation are: penetration into new markets i.e. improving the visibility level and presence of the 
product in the market as well as achieving large scale and sales frequency. The basic marketing tools, i.e. basic marketing mix elements (so-called the 4P - product, price, place, and promotion) are appropriate combination of components through which organizations achieve their own marketing objectives and reach sustainable competitive advantage (Kotler \& Keller, 2006).

Marketing innovation is based on the promotion of the four instruments that are inter-related and focused on meeting the consumer needs by achieving a sustainable competitive advantage (Ferrell \& Hartline, 2011). So, marketing innovation involves the use of completely new marketing strategies, marketing concepts or new marketing methods that have never been applied in the organization.

Figure 1, illustrates marketing innovation which are based on the combination of the following elements:

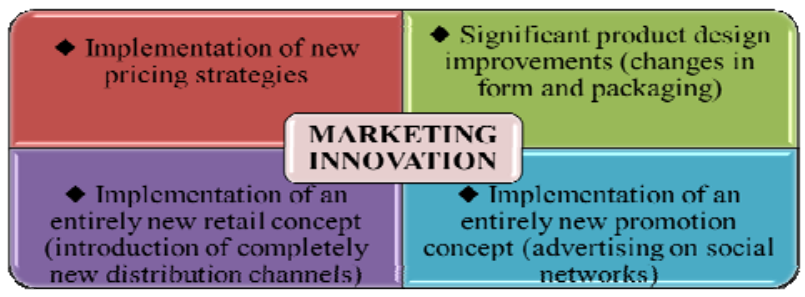

Figure 1. The elements of marketing innovation

Marketing innovation may be the introduction of a new interactive method of "online" on the organization website. "Online" service allows the consumer to choose the desired set of products on the organization's website and receive a price that is formed exclusively on the basis of individually selected product characteristics.

\section{Materials and methods}

Reviewing of current new technology and innovation in food service industry. Research materials in this article comprise secondary sources of information such as data of Eurostat, Statista, EUR-Lex - Europa EU, Smart Specialisation Platform, European Parliament business reports and industry newsletters and publications. The research period was in the years 2011-2016.

The work used a qualitative method - observation in the field of new innovation technologies in the food industry enterprises.

\section{Analyses and results}

The innovation technologies are also transforming how innovations are being conceptualized, designed and commercialized and, more generally, how businesses operate. For example, companies such as Kickstarter, Innocentive, Crowd Spring, Amazon, Google, and Salesforce have created online platforms that reduce the barriers to entry and transaction costs for innovators developing and commercializing new products of their own.

At present, the market of foodservice is entering the stage of saturation with support funds and it is clear that support centers un-der the name of center of innovation technology should be affiliated with science and research or R\&D centers. Development support centers of innovation technology in Poland as well as in the countries E.U., led to a clear division of the centers into so-called academic and those operating within the commercial market of innovation technology. Also would wanted that so to be in the Ukraine.

Consider the relation in countries between individuals and institutions (Inzelt, 2004) (Table 1).

Table 1

Types of interaction

\begin{tabular}{|c|c|c|}
\hline Between individuals & Between individuals and institutions & Between institutions \\
\hline $\begin{array}{l}\text { 1. Ad hoc consultations of firm employees } \\
\text { at universities }\end{array}$ & $\begin{array}{l}\text { 5. Buying university research results } \\
\text { (patents) ad hoc basis }\end{array}$ & $\begin{array}{l}\text { 12. Access to special equipment of } \\
\text { firm/university with or without assis- } \\
\text { tance of owner's organizations }\end{array}$ \\
\hline $\begin{array}{l}\text { 2. Lectures of firm employees held at } \\
\text { universities }\end{array}$ & $\begin{array}{l}\text { 6. Employing faculty members as regular } \\
\text { consultants }\end{array}$ & 13. Invest into university's facilitates \\
\hline $\begin{array}{l}\text { 3. Lectures of faculty members held at } \\
\text { firms }\end{array}$ & $\begin{array}{l}\text { 7. Coaching of firm employees by univer- } \\
\text { sity researchers }\end{array}$ & $\begin{array}{l}\text { 14. Regular acquiring university re- } \\
\text { search }\end{array}$ \\
\hline $\begin{array}{l}\text { 4. Regular (informal) discussions between } \\
\text { faculty members and firm employees on }\end{array}$ & $\begin{array}{l}\text { 8. Training of firm employees by univer- } \\
\text { sity professors }\end{array}$ & $\begin{array}{l}\text { 15. Formal } \mathrm{R} \& \mathrm{D} \text { co-operations such as } \\
\text { contract research }\end{array}$ \\
\hline \multirow[t]{3}{*}{$\begin{array}{l}\text { the meetings of professional associations, } \\
\text { at conferences, and seminars }\end{array}$} & $\begin{array}{l}\text { 9. Joint publications by university profes- } \\
\text { sors and firm employees }\end{array}$ & $\begin{array}{l}\text { 16. Formal } \mathrm{R} \& \mathrm{D} \text { co-operations such as } \\
\text { joint research projects }\end{array}$ \\
\hline & $\begin{array}{l}\text { 10. Joint supervision of Ph.D. and master } \\
\text { theses by university and firm members }\end{array}$ & $\begin{array}{l}\text { 17. Knowledge flows through perma- } \\
\text { nent or temporary mobility from uni- } \\
\text { versities to firms }\end{array}$ \\
\hline & $\begin{array}{l}\text { 11. Joint IPRs by university professors } \\
\text { and firm employees Arm's length }\end{array}$ & $\begin{array}{l}\text { 18. Knowledge flows through spin-off } \\
\text { formations of new enterprises }\end{array}$ \\
\hline
\end{tabular}

While food systems have been slow to benefit from innovative technologies (Statistics Portal, 2017; Central Statistical Office, 2017), especially in developing countries, a recent acceleration of innovation efforts make the future adoption of technology feasible. This report provides a glimpse of the novel technology applications companies are developing to address food systems challenges. These innovations have attracted more than $\$ 14$ billion in investments.

Highlighted most 5 countries (EU-28) (fig. 2), which turnover of the restaurants and mobile food service activities industry in 2016 made up: 47793,8 million euros - 
France (19\%), 46163,5 million euros - United Kingdom (19\%), 37452,1 million euros - Germany (15\%), 29785,3 million euros - Italy (12\%), 20203,5 million euros Spain (8\%).

They made up $73 \%$ market and the rest other countries $-27 \%$.
The careful attention that our contemporary society pays to the innovation technology is caused by the fact that technologies are a deciding factor of economic, social and innovative development at both regional and global levels (Shugurov, 2015).

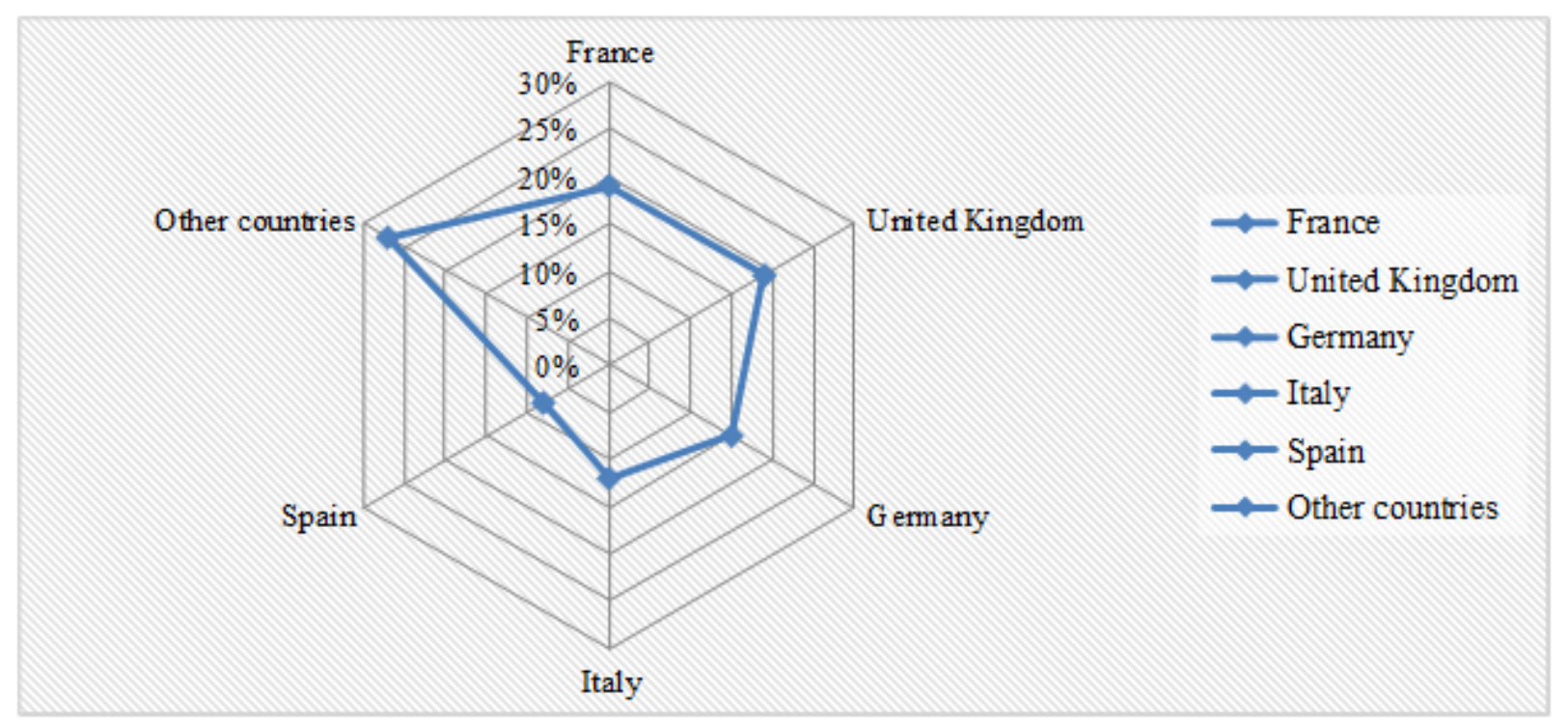

Figure 2. Number of enterprises in the restaurants and mobile food service activities industry in the European Union (EU-28) from 2011 to 2016

The emerging technologies have the potential to shape consumer diets and consumption behaviours in ways that could significantly impact food systems.

Smart appliances and indoor or urban farming can enable consumers to eat healthy and affordable homecooked meals with the convenience of processed readyprepared foods. Embedded microscopic electronic devices such as radiofrequency identification tags and genetic markers, as well as hyperspectral imaging, could be the barcodes of tomorrow. Used in combination with mobile phones, they could put information regarding the authenticity, freshness, ripeness, shelf life and nutritional content of food at people's fingertips. Advanced analytics, along with nutrigenetics, could allow people to get nutritional advice tailored to their ability to digest certain foods, dietary and health needs, and taste preferences. Connectivity technologies such as social networks, peer-to-peer networks and online e-commerce could provide platforms to significantly influence consumption patterns and increase access to nutritious foods. Aware of the environmental and nutritional implications of the production and consumption of certain foods, consumers may demand information which be made availablethat their food meet minimum sustainability and health requirements.

\section{Discussion}

Market orientation is one of the factor that is vital to innovation. To survive and sustain in a competitive environment, firms must create a sustainable competitive advantage (SCA) that can achieve market performance (Narver \& Slater, 1990). To create and sustain a SCA, a market-orientation culture is effective since it would continuously examine the sources of SCA in order to create "additional benefits" for customers and types of reductions in the customers' total purchase costs (Narver \& Slater, 1990).

Given the purpose of market orientation, customer and competitor orientations are involved together as they could engage most of the activities necessary to acquire information about the customers and competitors in the target market, and thereby satisfy customer needs better than their competitors (Narver \& Slater, 1990). Market orientation might spur innovation for the reason that a market-oriented firm may have superior marketingsensing and customer-linking capabilities, and thus be in a position to innovate to provide superior value for its target customers (Narver \& Slater, 1990; Agarwal et al., 2003), though such relationship is also subject to the types of innovation (Anon, 2008), industy distinctions (Agarwal et al., 2003) and innovation characteristics that a firm possesses (Berry \& Taggart, 1994).

\section{Conclusions}

Companies can gain sustainable competitive advantage through differentiation based on creating a single common value concept for consumers and contributing to sustainable development. Sustainable development is an important aspect of marketing.

Besides economic viability, company must achieve the goals of environmental sustainability. The companies preferred in the contemporary economic conditions are the ones managing to link innovation and marketing suc- 
cessfully. Innovation can be seen as an asset of the company, which is directly related to the feedback of marketing. Innovation is the main driver of competitiveness. In today's digital era it is important to make maximum use of new communication technologies and the Internet especially in marketing and sales. The real challenges lie ahead of the company management: which marketing tools to retain and amplify, which ones to leave out and which sales strategy is the most effective. Nowadays, it is not just enough to know what consumers are looking for. Those who are familiar with market trends can predict which products consumers will put emphasis on. The changes have become more frequent and more distinct.

The recent advancements in Fourth Industrial Revolution technologies present a major opportunity to accelerate food systems transformation. These technologies could fundamentally shape the demand landscape, enhance value-chain linkages and increase the effectiveness of the production landscape. While many of these technological innovations are in the early stages of development, these technologies could deliver significant positive impacts in food systems by 2030 , if scaled properly.

\section{References}

Agarwal, S., Krishna Erramilli, M., \& Dev, C.S. (2003). Market orientation and performance in service firms: role of innovation. Journal of Services Marketing, 17(1), 68-82. doi: 10.1108/08876040310461282.

Anon (2008). Whitbread gets the right blend for training: E-learning combined with classroom teaching benefits company and employees. Human Resource Management International Digest, 16(7), 18-20.

Berry, M.M.J., \& Taggart, J.H. (1994). Managing Technology and Innovation: A Review. R\&D Management, 24(4), 341-353. doi: 10.1111/j.14679310.1994.tb00889.x.

Craft, B., Tshering, K., Machulu Onduri, F., \& Funsani Gama, S. (2015). Technology Development and Transfer, the Least Developed Countries and the Future Climate Regime. Considerations for the post2020 international response to climate change. https://pubs.iied.org/G04039/?k=G04039.

Chung, W. (2001). Identifying Technology Transfer in Foreign Direct Investment: Influence of Industry Conditions and Investing Firm Motives. Journal of International Business Studies, 32(2), 211-229. doi: $10.1057 /$ palgrave.jibs.8490949.

Central Statistical Office (2017). Concise Statistical Yearbook of Poland. Year LX, Warsaw.

Davis, B., Lockwood, A., Pantelidis, I., \& Alcott, P. (2008). Food and Beverage Management (4th ed), London, Elsevier.

Ferrell, O.C., \& Hartline, M.D. (2011). Marketing strategy (5th ed.). Mason, OH: South-Western Cengage Learning.

Girifalco, L.A. (1991). Dynamics of Technological Change, Van Nostrand Reinhold, New York.

Inzelt, A. (2004). The evolution of university-industrygovernment relationships during transition, Research Policy, 33(6-7), 975-995. doi: 10.1016/j.respol.2004.03.002.

Kanyak, E. (1999). Transfer of Technology from Developed Countries. CT: Quarum Books.

Kidder, T. (2000). The Soul of a Machine. Massachusetts: Little Brown.

Kotler, P., \& Keller, K. (2006). Marketing management (12th ed.). New Jersey: Prentice Hall.

Lee, S., Barker, S., \& Kandampully, J. (2003). Technology, service quality, and customer loyalty in hotels: Australian managerial perspectives. Managing Service Quality, 13(5), 423-432. doi: 10.1108/09604520310495886.

Maskus, K.E. (2004). Encouraging International Technology Transfer. UNCTAD/ICTSD. Intellectual Property Rights and Sustainable Development, 7. https://unctad.org/en/pages/PublicationWebflyer.aspx?p ublicationid $=2195$.

Narver, J.C., \& Slater, S.F. (1990). The effect of a market orientation on business profitability. The Journal of Marketing, 54(4), 20-35. doi: 10.2307/1251757.

Phillips, R. (2002). Technology Business Incubators: How Effective Is Technology Transfer Mechanisms? Technology in Society, 24(3), 299-316. doi: 10.1016/S0160-791X(02)00010-6.

Pilato, M., Séraphin, H., Bellia, C., \& Căescu, Ș. (2017). Challenging the Negative Image of Destinations at Previsit Stage Using Food and Food Events as an Educational Tool: The Case of Romania. Journal of Emerging Trends in Marketing and Management, 1(1), 35-45. https://ideas.repec.org/a/aes/jetimm/v1y2017i1p3545.html.

Prasad, M., Scornavacca, E., \& Lehmann, H. (2005). Using wireless personal digital assistants in a restaurant: impact and perceived benefits. International Conference on Mobile Business. Sydney Australia. doi: 10.1109/ICMB.2005.112.

Putranto, K., Stewart, D., \& Moore, G. (2003). International Technology Transfer of Technology and Distribution of Technology Capabilities: The Case of Railway Development in Indonesia. Technology in Society, 25(1), 42-53, doi: 10.1016/S0160791X(02)00035-0.

Radosevic, S., \& Ciampi Stancova, K. (2018). Internationalising Smart Specialisation: Assessment and Issues in the Case of EU New Member States. Journal of the Knowledge Economy, 9(1), 263-293, http://rd.springer.com/article/10.1007/s13132-0150339-3.

Riley, M. (2005). Food and Beverage Management: A review of Change. "International Journal of Contemporary Hospitality Management”, 17(1), 88-93. doi: 10.1108/09596110510577707.

Sahal, D. (1977). The Multidimentional Diffusion of Technology. Technological Forecasting and Social change, 10(3), 277-298. doi: 10.1016/00401625(77)90025-7.

Scott, D.M. (2013). The new rules of marketing \& PR: How to use social media, online video, mobile applications, blogs, news releases, and viral marketing to reach buyers directly (4th ed.). Hoboken, N.J: John Wiley \& Sons.

Shugurov, M.V. (2015). TRIPS Agreement, International 
Technology Transfer and Least Developed Countries. Journal of Advocacy, Research and Education, 2(1), 74-85. http://kadint.net/journals_n/1430116707.pdf.

Slack, N., Chambers, S., \& Johnston, R. (2007). Operations Management, 5th ed Essex: Prentice Hall.

Smith, D.K., \& Alexander, B.C. (1999). Fumbling the Future: How Xerox Invented, the Ignored, the First Personal Computer. New York: William morrow.

Tidd, J., \& Bessant, J. (2009). Managing Innovation: Integrating Technological, Market and Organizational
Change, 4th Ed. Chichester: Wiley.

Woon Gon, K., \& Sunny, H. (2006). The Impact of Information Technology Implementation on Service Quality in the Hotel Industry. Information Technology in Hospitality, 4(4), 143-151. doi: $10.3727 / 154595306779868430$.

The Statistics Portal: https://www.statista.com/topics/ 3966/restaurants-and-food-services-in-europe (accessed: 11.11.2017). 